\title{
Synthesis and Characterization of Bacterial Cellulose - Garcinia mangostana Extract as Anti Breast Cancer Biofilm Candidate
}

\author{
Agrippina Waya Rahmaning Gusti ${ }^{1, a}$, Prihartini Widiyanti ${ }^{1,2, b^{*}}$ \\ and Helmy Yusuf $3, \mathrm{c}$
}

\author{
${ }^{1}$ Biomedical Engineering Program, Faculty of Science and Technology, Universitas Airlangga, \\ Indonesia \\ ${ }^{2}$ Institute of Tropical Disease, Universitas Airlangga, Indonesia \\ ${ }^{3}$ Pharmaceutical Department, Faculty of Pharmacy, Universitas Airlangga, Indonesia \\ aagrippinawrg@gmail.com, bpwidiyanti@fst.unair.ac.id, chelmy.yusuf@gmail.com \\ *Corresponding author: pwidiyanti@fst.unair.ac.id
}

Keywords: biofilm, bacterial cellulose, mangosteen peel extract, breast cancer

\begin{abstract}
In Indonesia, breast cancer is noted as the most common cancer in women. Accordingly, this research was conducted to synthesize biofilm from bacterial cellulose by adding ethanol extract of mangosteen peel. The pellicle of bacterial cellulose was soaked in a $100 \mathrm{~mL}$ ethanol solution of mangosteen peel extract varied by $0.5 \%, 1 \%, 1.5 \%$, and $2 \% \mathrm{v} / \mathrm{v}$. The samples were characterized using the SEM, FTIR, and MTT Assay using the T47D breast cancer cells. The results using the SEM showed the thickness of the bacterial cellulose biofilm samples was $5.63 \mu \mathrm{m}$, while the $2 \%$ $\mathrm{v} / \mathrm{v}$ thickness of the bacterial cellulose of the extract of mangosteen peel biofilm samples was $12.2 \mu \mathrm{m}$. The FTIR results showed a weak interaction between the $\mathrm{O}-\mathrm{H}$ groups of the microbial cellulose and the $\mathrm{C}=\mathrm{C}$ functional group in the phenolic compounds of the mangosteen peel extract. Based on the MTT Assay test results using the T47D breast cancer cells, the highest percentage of cell death result was $25.47 \%$ on the $2 \% \mathrm{v} / \mathrm{v}$ bacterial cellulose of the mangosteen peel extract samples. The Garcinia mangostana extracts added in the bacterial cellulose biofilms still required optimal concentrations in order to become potential killing mechanism for the T47D breast cancer cells.
\end{abstract}

\section{Introduction}

According to WHO 2012, cancer is one of the major causes of morbidity and mortality worldwide with approximately 14 million new cases and 8.2 million deaths caused by lung, liver, stomach, colorectal, and breast cancers. Cancer is also the second most common cause of death in the world by $13 \%$ after cardiovascular disease. The number of new cases related to cancer is predicted to increase about $70 \%$ over the next two decades. In women, the five leading cases of cancer, among others, are breast, colorectal, lung, cervical, and stomach cancers.

Nationally, the prevalence of cancer among all ages in Indonesian population in 2013 was amounted to $1.4 \%$ or about 347,792 people [14]. In Indonesia, the most common types of cancers in women are breast and cervical cancers; whereas in men are lung and colorectal cancers. In East Java, breast cancer alone was diagnosed in an estimate of 21,313 patients in 2013 [7].

According to the 2015 American Cancer Society, breast cancer can be caused by gene mutations due to hereditary factors and triggered by numerous risk factors, which include age, genetics, tobacco smoking, alcohol consumption, physical inactivity, and so forth. The risk of having breast cancer is increasing with age. Heavy alcohol consumption will increase the risk of cancer, not only breast cancer but also other types of cancers. Approximately $5-10 \%$ breast cancer incidence is caused by genetic factors.

Breast cancer treatments can be done in various ways, such as surgery, radiotherapy, chemotherapy, hormone therapy, and a variety of other therapies. Chemotherapy has many bad side effects, namely hair loss, nausea, vomiting, loss of appetite or increased appetite precisely, and 
decreased number of blood cells [3]. Similarly, radiotherapy, hormone therapy, and other therapies also have negative impacts. Therefore, better methods to cure breast cancer are required.

Many studies have been conducted to learn better treatment methods for breast cancer. One that has been successfully carried out is the crystallization of mangosteen peel extract. Mangosteen peel contains bioactive compounds, xanthones, more than $90 \%$ ( $\alpha$-mangostin by $80-90 \% ; \gamma$-mangostin by $5-10 \%$ ); called Panaxanthone and is considered safe according to the conventional security test using mice as a trial model. Xanthones have been used as medicine in the community for many years [2]. At present, clinical trials regarding the safety of Panaxanthone as preventive agent and cancer therapy are still conducted. The drug that is taken orally enters the body through various kinds of digestive organs inside the body. Consequently, the medicine cannot reach the target organ directly.

Accordingly, it requires a special method to pack the drugs and bioactive compounds into the natural polymer material (biopolymer); in which case, the compound is expected to be released precisely on the target. One of them is by synthesizing the biomaterials coated with bacterial cellulose of the mangosteen peel extract. The bacterial cellulose films added with mangosteen peel extract show significant cytotoxic effects against B16F10 and MCF-7 cancer cells. Cancer cells that are cultured on bacterial cellulose films with $0.1 \%$ and $1 \% \mathrm{v} / \mathrm{v}$ of round mangosteen peel extract concentrations have shrunk and undergone damage on the membrane [18].

Mangosteen (Garcinia mangostana) contains xanthones bioactive compounds, such as gartanin, $\gamma$-mangostin, $\alpha$-mangostin and many others on its peel with a variety of benefits in terms of biological properties, such as antioxidant, antibacterial against Staphylococcus aureus as well as Escherichia coli, anti-inflammatory and anticancer without showing its toxic properties to the normal cells [18]. The xanthones bioactive compounds can be isolated from the mangosteen's peels, fruits, stems, leaves, and branches [5].

Bacterial cellulose was selected as biopolymer on bacterial cellulose films by adding mangosteen peel extract because it can produce nanocellulose with a friendly environmental process using Acetobacter xylinum bacteria [9], show good liquid absorbing properties, and does not cause irritation. The bacterial cellulose was processed into a film, which then was soaked in mangosteen peel extract solution under ambient conditions for 24 hours. The bacterial cellulose served as a matrix to control the release of the ethanol extract of the mangosteen peel [18]. It is expected that the application of bacterial cellulose films with the addition of mangosteen peel extracts can be an effective method of drug delivery for cancer treatment. In addition, the polymer film made of bacterial cellulose is potentially increasing the efficacy and decreasing the side effects as compared to the oral therapy [12].

The previous study [18] performed a variation of mangosteen peel extract concentration of 0.01 , 0.10 , and $1 \% \mathrm{v} / \mathrm{v}$; and the result obtained was that the viability of B16F10 melanoma and the MCF7 breast cancer cells treated with bacterial cellulose films containing mangosteen peel extract showed significant cytotoxic effects against the B16F10 melanoma cells and the MCF-7 breast cancer cells. In the study of anti-cancer ability, the bacterial cellulose films containing $1 \% \mathrm{v} / \mathrm{v}$ mangosteen peel extract with the release of $\alpha$-mangostin more than 17.4 to $18.4 \mu \mathrm{g} / \mathrm{ml}$ of bacterial cellulose films were able to suppress the growth of B16F10 melanoma (less than $15 \%$ survived) and the MCF-7 breast cancer cells (less than 5\% survived).

This research was conducted to synthesis the bacterial cellulose films with varying concentrations of mangosteen peel extract of $0.5 \%, 1 \%, 1.5 \%$, and $2 \% \mathrm{v} / \mathrm{v}$ which were respectively equivalent to the concentrations of mangosteen peel extract of $0.5,1,1.5$, and $2 \mathrm{~mL}$ to determine the effectiveness of the active compound of the mangosteen peel in suppressing the growth of cancer cells and later in characterizing them. The concentration of $1 \% \mathrm{v} / \mathrm{v}$ of the mangosteen peel extract were best in the previous study. Therefore, this study referred to those results, that is, to synthesize the bacterial cellulose films with the addition of mangosteen peel extract using some samples containing concentrations of mangosteen peel extract below and above the best concentrations. The characterizations of this study, that is, the morphology test using the Scanning Electron Microscopy (SEM) to determine the morphology and the thickness of the samples; the functional group analysis 
test with Fourier Transform Infra Red (FTIR) to analyze the functional group materials; and the cytotoxicity test (Methyl Thiazolyl Tetrazolium Assay/MTT Assay) with the T47D breast cancer cells were to determine the viability of the cancer cells. The cancer cells used were the T47D breast cancer cell type.

\section{Research Methods}

\subsection{Tools and Materials}

The equipment used for the bacterial cellulose film synthesis with the addition of mangosteen peel extract included digital balance, glass beaker, stove, pots, micropipette, $\mathrm{pH}$ meter, thermometer, a petri dish, measuring cups, spatulas, the fermentation container, $5 \mathrm{~mL}$ syringe, incubator, and sterilizer. The test equipment used comprised Scanning Electron Microscopy Hitachi TM3000, Fourier Transform Infra Red Thermo Scientific Nicolet iS10, and a set of MTT Assay test equipment. Materials used consisted of Acetobacter xylinum, coconut water, sucrose, acetic acid, yeast extract (OXOID), $\mathrm{NaOH}$ (SAP Chemicals), aquades, the soft parts of mangosteen peel, 96\% ethanol (SAP Chemicals), and T47D breast cancer cells from Cancer Chemoprevention Research Center UGM (CCRC-UGM).

\subsection{Bacterial Cellulose Biofilm Synthesis with the Addition of Mangosteen Peel Extract}

The bacterial cellulose biofilm synthesis began by mixing $1.5 \mathrm{~L}$ filtered coconut water, $30 \mathrm{~mL}$ acetic acid, 150 grams of sucrose, and 3.5 grams of laboratory special yeast extract that were heated to boil. Then, the respectively culture medium of $300 \mathrm{~mL}$ was placed in 5 containers that had been autoclaved and let to stand cool for 6 hours; and as much as $30 \mathrm{~mL}$ bacteria starter of Acetobacter xylinum was added in each container [16]. Media were incubated for 2-3 days to form a pellicle with a thickness of about 1-2 mm, and were then washed with running water for 30 minutes. Next, $1 \% \mathrm{w} / \mathrm{v} \mathrm{NaOH}$ was added to soak the bacterial cellulose films for 24 hours. Later on, the bacterial cellulose films were soaked in distilled water until a neutral $\mathrm{pH}$ was close to 7 [18].

The mangosteen peel extract was made using maceration method obtained from the Department of Pharmacognosy and Phytochemistry, Faculty of Pharmacy, Universitas Airlangga. The mangosteen peel extract with various concentrations of $0.5 \% \mathrm{v} / \mathrm{v}, 1 \% \mathrm{v} / \mathrm{v}, 1.5 \% \mathrm{v} / \mathrm{v}$, and $2 \%$ $\mathrm{v} / \mathrm{v}$ was diluted in $96 \%$ ethanol. Pure bacterial cellulose films were immersed in a solution of ethanol extract of mangosteen peel to conform with the concentration variations of the mangosteen in an ambient condition for 24 hours and rinsed with $20 \%(\mathrm{v} / \mathrm{v})$ ethanol solution. During the immersion, the sample solution of $0.5 \mathrm{~mL}$ was drawn every hour; and at the 24th hour, it was then replaced with the same $96 \%$ ethanol volume. The films were dried at $30^{\circ} \mathrm{C}$ room temperature for 4 days. The ethanol in the biofilm had evaporated during the drying process.

\subsection{Functional Group Analysis using Fourier Transform Infra Red (FTIR)}

The FTIR test was conducted to analyze the functional groups found in the sample by observing the absorption of the infrared radiation at various wavelengths. A solid sample to be tested was cut to small piece sized $1 \mathrm{~mm}$ and placed in the FTIR indicator. The infrared spectrum, which was used to test samples, was at a wavelength of $4000-200 \mathrm{~cm}^{-1}$. The results obtained were in the form of an area chart absorption wave numbers graph $\left(\mathrm{cm}^{-1}\right)$ against the presentation transmittance $(\%)$.

\subsection{Morphology Test using Scanning Electron Microscopy (SEM)}

Morphology test using the SEM was performed to determine the surface morphology and the thickness of the bacterial cellulose film sample with the addition of mangosteen peel extract. The SEM test results were sample surface photos along with the film thickness size.

The sample preparation procedures for the SEM test were initiated by cutting the samples to a $10 \mathrm{~mm}$ size. The sample was then affixed to the double-sided tape conductive. The coating process was performed by using the Quorum Q150RS machine.

Subsequently, the sample morphology was observed with a Hitachi TM3000 electron microscope (SEM) with a magnification of 1800-3000X. 


\subsection{Cytotoxicity test using MTT Assay}

Cytotoxicity test was performed using MTT method. The T47D breast cancer cells were incubated for 24 hours in 96-well plate that contain cell medium. Biofilms were immersed in cell medium for an hour to neutralize the $\mathrm{pH}$. This immersion was intended to guarantee that no harm might be caused by tracer of ethanol. After immersion, the medium was discarded and square cut of biofilms were incubated with the T47D breast cancer cells in 96-well plate for 20 hours. After incubation, $25 \mu \mathrm{L}$ MTT reagent was added to each well and incubated for 4 hours. Then the optical density were measured using Elisa Reader and the percentage of living cells was calculated using equation (1).

$$
\text { Living Cell } \%=\frac{\text { Treatment OD }- \text { Media Control OD }}{\text { Cell Control OD }- \text { Media Control OD }} \times 100 \%
$$

Value of cell control optical density wherein :

$$
\begin{array}{ll}
\text { Treatment OD } & =\text { value of sample optical density after treatment } \\
\text { Cell Control OD } & =\text { value of cell control optical density } \\
\text { Media Control OD } & =\text { value of media control optical density } \\
\text { Living Cell \% } & =\text { percentage of cell numbers after treatment }
\end{array}
$$

\section{Results and Discussion}

3.1 Cluster Analysis Functions using Fourier Transform Infra Red (FTIR)

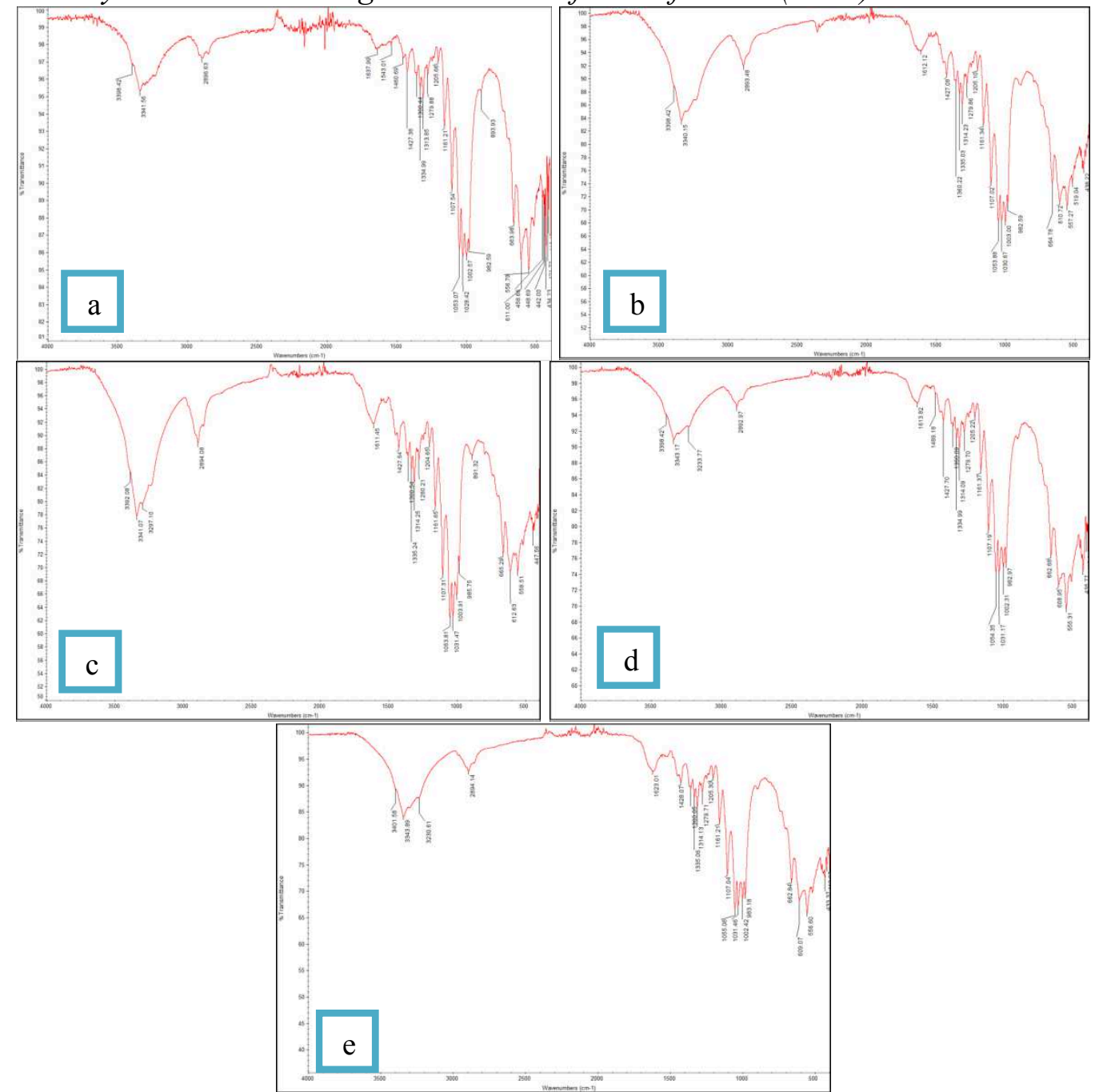

Figure 1. FTIR Results of (a) BC film, (b) BC-0.5\% Extract, (c) BC-1\% Extract, (d) BC-1.5\% Extract and (e) BC-2\% Extract 
Table 1. Functional Cluster Identification on Samples

\begin{tabular}{|c|c|c|}
\hline Sample Type & Peak & Functional Clusters \\
\hline Control & 3398 & O-H stretching \\
(Bacterial Cellulose) & 1107 and 1053 & C-O-C asymmetric stretching \\
\hline Sample A & 3398 & O-H stretching \\
$(0.5 \%$ BC-Extract) & 1612 & C=C stretching \\
& 1107 and 1053 & C-O-C asymmetric stretching \\
\hline Sample B & 3392 & O-H stretching \\
$(1 \%$ BC-Extract $)$ & 1611 & C=C stretching \\
& 1107 and 1053 & C-O-C asymmetric stretching \\
\hline Sample C & 3398 & O-H stretching \\
$(1,5 \%$ BC-Extract $)$ & 1613 & C=C stretching \\
& 1107 and 1054 & C-O-C asymmetric stretching \\
\hline Sample D & 3401 & O-H stretching \\
$(2 \%$ BC-Extract $)$ & 1623 & C=C stretching \\
& 1107 and 1055 & C-O-C asymmetric stretching \\
\hline
\end{tabular}

FTIR results showed some absorption areas of functional clusters characterizing the materials used. Wave number $3398-3401 \mathrm{~cm}^{-1}$ on the samples showed $\mathrm{OH}$ stretching vibrations. Meanwhile, vibrations at wave number $1050-1150 \mathrm{~cm}^{-1}$ were the $\mathrm{C}-\mathrm{O}-\mathrm{C} \beta$-glycosidic bond absorptions [16]. In the samples containing mangosteen peel extract, there were vibrations at wave number 1611$1623 \mathrm{~cm}^{-1}$ on the samples indicating the $\mathrm{C}=\mathrm{C}$ clusters in the aromatic phenol compounds, which signified the typical compound in the mangosteen peel extract [18].

In Figure 1, the peak representing the hydroxyl clusters in sample A, sample B, sample C, and sample D experienced a slight shift. In sample A, hydroxyl cluster vibrations were shown at wave number $3398 \mathrm{~cm}^{-1}$, sample $\mathrm{B}$ at wave number $3392 \mathrm{~cm}^{-1}$, sample $\mathrm{C}$ at wave number $3398 \mathrm{~cm}^{-1}$, and sample D at wave number $3401 \mathrm{~cm}^{-1}$ [16]. In sample $\mathrm{A}$, the $\mathrm{C}=\mathrm{C}$ functional clusters in the phenolic compounds were shown at wave number $1612 \mathrm{~cm}^{-1}$, sample B at wave number $1611 \mathrm{~cm}^{-1}$, sample C at wave number $1613 \mathrm{~cm}^{-1}$, and sample $\mathrm{D}$ at wave number $1623 \mathrm{~cm}^{-1}$. The peak shift may indicate a weak interaction between the hydroxyl clusters of bacteria cellulose with the functional clusters of the bioactive compounds in the extracts [18].

\subsection{Cytotoxicity test using MTT Assay}

Cytotoxicity test (MTT Assay) was conducted using the T47D breast cancer cells to determine the percentage of the T47D breast cancer cells that are still alive after being treated with the bacterial cellulose film samples with the addition of mangosteen peel extract. The living cells will form purple formazan crystals. The T47D cells were cultured on well plates incubated for 24 hours. The samples were incubated in well plate that contain T47D cells for 20 hours. And then the medium and samples were discarded and later on the well plates was washed using Phosphate Buffer Saline (PBS). The MTT reagents were added into each well-plate before incubated for 4 hours, and the MTT reactions were stopped by adding Dimethyl Sulfoida (DMSO) solution. The well-plates were put in the ELISA Reader to obtain the Optical Density (OD) values required to calculate the percentage of living cells. 
Table 2. Cytotoxicity Test Results of Bacteria Cellulose Biofilm Mangosteen Peel Extract

\begin{tabular}{|c|c|}
\hline Sample & $\begin{array}{c}\text { Living Cell } \\
\text { Percentage Average }\end{array}$ \\
\hline $\begin{array}{c}\text { Pure BC } \\
\text { (Control Sample) }\end{array}$ & $60.61 \pm 7.99 \%$ \\
\hline $\begin{array}{c}0.5 \% \text { BC:Extract } \\
\text { (Sample A) }\end{array}$ & $105.01 \pm 10.35 \%$ \\
\hline $\begin{array}{c}1 \% \text { BC:Extract } \\
\text { (Sample B) }\end{array}$ & $95.98 \pm 3.6 \%$ \\
\hline $\begin{array}{c}1,5 \% \text { BC:Extract } \\
\text { (Sample C) }\end{array}$ & $93.05 \pm 8.60 \%$ \\
\hline $\begin{array}{c}2 \% \text { BC:Extract } \\
\text { (Sample D) }\end{array}$ & $74.53 \pm 7.55 \%$ \\
\hline
\end{tabular}

Data on Table 4.2 can be illustrated on the percentage graph of the T47D living cells:

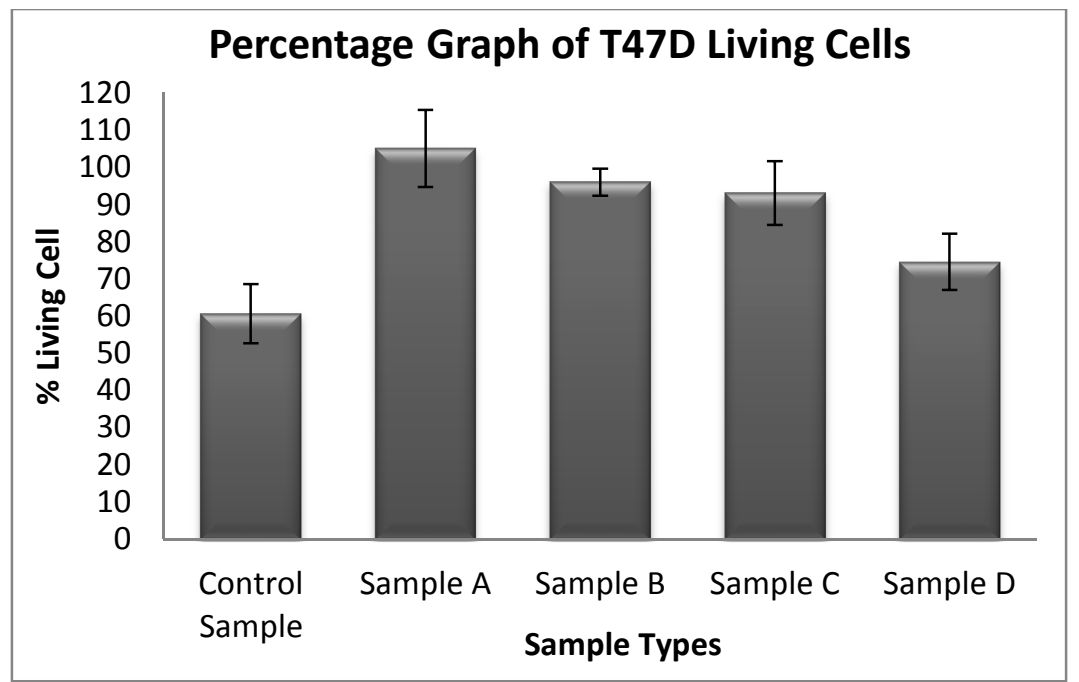

Figure 2. Percentage Graph of T47D Living Cells

Based on Figure 2 of the percentage graph of T47D living cells, the percentage of T47D living cells in the control sample is the lowest amounting to $60.61 \%$. Sample A has the T47D cell survival percentage by $105.01 \%$; sample B by $95.98 \%$; sample C by $93.05 \%$; and sample D by $74.53 \%$. According to statistical analysis of MTT Assay test result, all biofilms had a significant (doseindependent) inhibitory effect on proliferation of T47D cells $(\mathrm{p}<0.05)$. The control sample had the lowest T47D cell survival percentage because the $\mathrm{pH}$ of the sample was under acidic condition which could lead to the death of the T47D cells under acidic condition.

Based on the MTT Assay test results of 24 hours using the T47D breast cancer cells, sample A contained the lowest extract concentration, that is $0.5 \%(\mathrm{v} / \mathrm{v})$; ethanol extracts of mangosteen peel stimulated the T47D cells to grow so that the percentage of living cells was $105.01 \%$. It is possible because in the first 24 hours, the lowest extract concentrations contained in the biofilms showed less toxic effects on the T47D cells; therefore, it might take more than 24 hours to incubate the samples into the cells. One of the factors that influence the success of the MTT Assay test is the appropriate incubation period [17]. The tamoxifen sample incubation period combined with PQ1 against the appropriate T47D cells was 48 hours. The incubation period of 48 hours significantly causes a decrease in the T47D living cell percentage [11]. The cell viability was affected by a variety of cell functions, such as, enzyme activity, cell membrane permeability, cell adhesion, the ATP production, co-enzymes production, and nucleotides uptake activity [8]. 
The incubation period of the cells after the addition of the appropriate MTT reagents was required to produce an adequate fluorescence signal. The cell incubation period was usually 1-4 hours depending on one of the factors, namely metabolic activity of the cell types [17]. In the T47D cells, the incubation period after the addition of the MTT Assay reagents was 1 hour at $37^{\circ} \mathrm{C}$ [11].

In sample B, the percentage of T47D cell survival was $95.98 \%$ or cell death $4.02 \%$. Based on the results, the ethanol extract of mangosteen peel started to show the effects of the T47D cell death. Similarly, in samples C and D the percentage of cell death was $6.95 \%$ and $25.47 \%$ respectively. Sample D had the highest percentage of cell death because the concentration of the ethanol extract of mangosteen peel contained therein had the highest concentration as compared to sample A, sample $\mathrm{B}$, and sample $\mathrm{C}$. The increasing concentrations of the ethanol extract of mangosteen peel was related to the percentage of the T47D breast cancer cell death. The higher the concentration of the ethanol extract of mangosteen peel, the higher the percentage of the T47D cell death as illustrated in Figure 3 below:

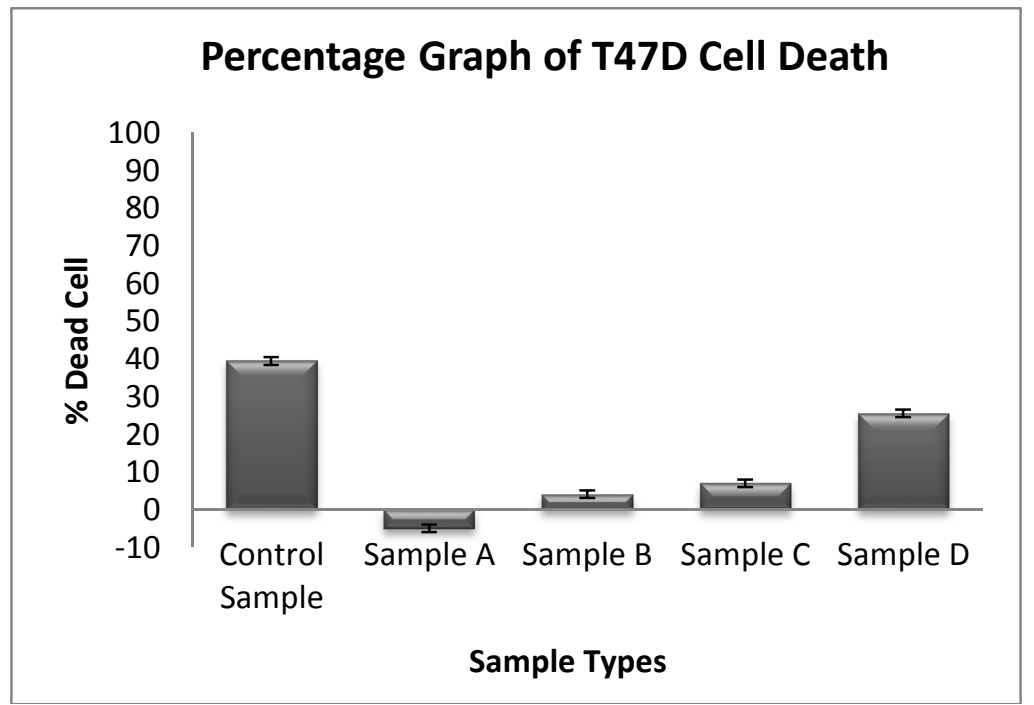

Figure 3. Percentage Graph of T47D Cell Death

In the study [18], the samples of bacteria cellulose biofilms containing $1 \%(\mathrm{v} / \mathrm{v})$ ethanol extract of mangosteen peel were able to kill $95 \%$ of the MCF-7 breast cancer cells. Meanwhile, in this study the samples of bacteria cellulose biofilms containing $1 \%(\mathrm{v} / \mathrm{v})$ ethanol extract of mangosteen peel, that is sample B, could only kill $4.02 \%$ of the T47D breast cancer cells. This is due to the characteristics of the MCF-7 cells which was different from the T47D cells.

The MCF-7 cells are classified as low level while the T47D cells are classified as moderate level based on the degree of the expression of estrogen receptor (ER) of cells [6]. The MCF-7 cells have lower level of ER expression than the T47D cells [4]. Therefore, the higher the ER degree of a cancer cell, the higher the rate of the cancer cell proliferation will be. In addition, the T47D cells contained proteins involving in cell growth stimulation, anti-apoptosis mechanisms and carcinogenesis that were stronger than in the MCF-7 cells. These proteins include Prohibitin serving as an anti-apoptosis, G1/S-specific cyclin-D3 functioning as cell cycle control, and Nuclear Hcc-1 protein functioning in the process of cell growth and carcinogenesis [2]. The T47D cells also have high cell proliferation rate [10]. Based on mitochondrial spare capacity, the T47D cells have higher mitochondria spare capacity than the MCF-7 cells indicating that the T47D cells adapt better to stress as compared to MCF-7 cells that support cell survival and avoid apoptosis [15].

\subsection{Morphology test using Scanning Electron Microscopy (SEM)}

The morphology sample is observed using a Scanning Electron Microscopy (SEM). Through the SEM not only the morphology sample is known but also the thickness of the sample. Figure 4 is the SEM results of the sample of the bacterial cellulose film control: 


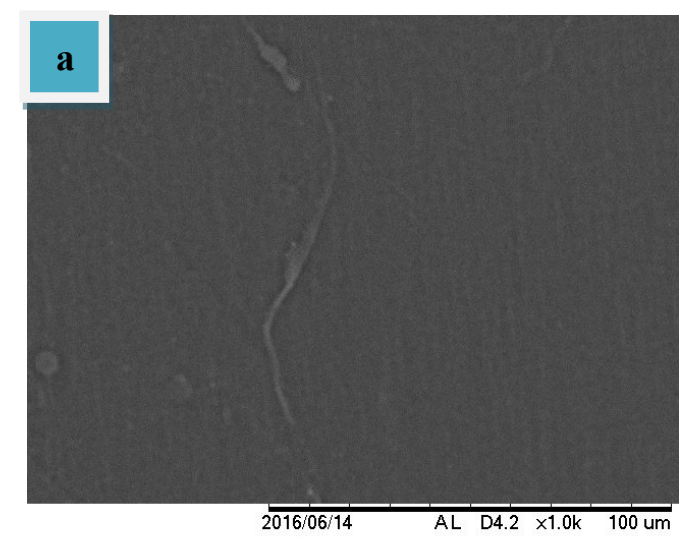

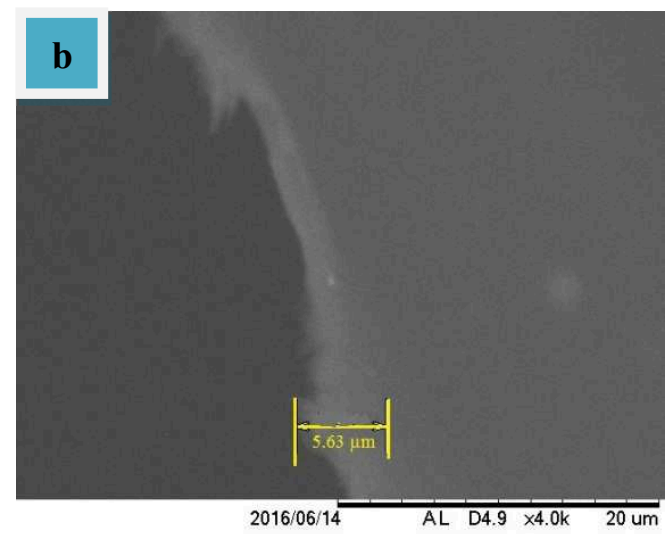

Figure 4. (a) Surface Area of Bacterial Cellulose Film Control with 1000X Magnification (b) Cross Section Area of Bacterial Cellulose Film Control with 4000X Magnification

In Figure 4 (a), the bacterial cellulose film control sample appeared to have smooth structure or very little fiber. This bacterial cellulose control sample was dried at room temperature, thus its structure became solidified and lost the porous structure. Unlike the bacterial cellulose sample which was not dried, it had a nice porous structure and supported the contents of drugs from the particles of the mangosteen peel extract. In addition, due to the lack of the SEM testing device the display of the sample surface looked unclear. The bacterial cellulose control sample had a thickness of $5.63 \mu \mathrm{m}$.
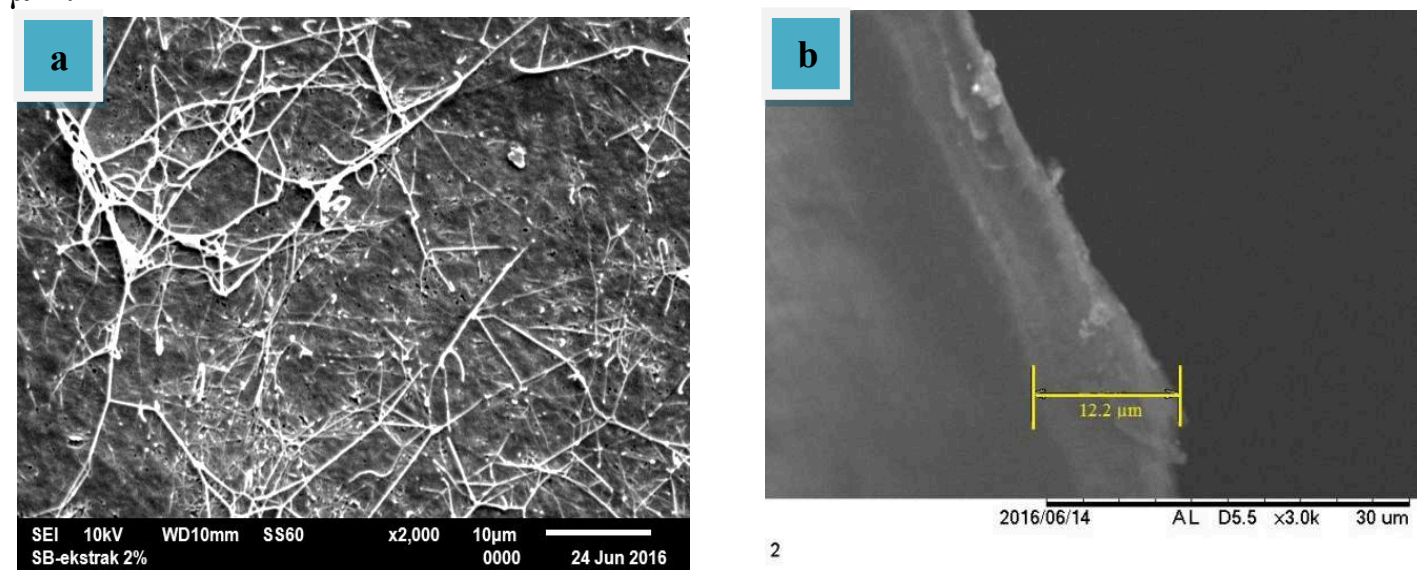

Figure 5. (a) Surface Area of the 2\% Film of Bacterial Cellulose - Garcinia mangostana Extract with 2000X Magnification (b) Cross Section Area of the 2\% Film of Bacterial Cellulose Garcinia mangostana Extract with 3000X Magnification

In Figure 5 (a), the $2 \%$ of the bacterial cellulose mangosteen peel extract sample seemed to have more fiber than the control sample. The lack of the SEM testing device caused the display surface of the sample looked unclear. To determine the thickness of the sample, the cross section observation was therefore conducted by using the SEM device.

The similar values of the bacterial cellulose film thickness were varied due to the uneven growth of bacteria on each side. In the control sample, the bacterial cellulose film thickness was $5.63 \mu \mathrm{m}$, however in the $2 \%$ of bacterial cellulose-extract sample the thickness was higher, that is $12.2 \mu \mathrm{m}$ as presented in Table 3.

Table 3. Value of Sample Thickness

\begin{tabular}{|c|c|}
\hline Sample & Thickness \\
\hline BC Control & $5.63 \mu \mathrm{m}$ \\
\hline BC- $2 \%$ Extract & $12.2 \mu \mathrm{m}$ \\
\hline
\end{tabular}


An increase in the film thickness possibly indicated the existence of particles of mangosteen peel extract trapped in the pores of the bacterial cellulose films that had not been dried. The particles remained in the dry bacterial cellulose films and would be released after the bacterial cellulose films were attached to the surface in a moist environment or immersed in liquid [18].

Based on the SEM test results, the biofilm thickness values were in the general range of biofilms between 5-500 $\mu \mathrm{m}$ [13]. However, according to the results of the study [18], the thickness of the bacterial cellulose control film was approximately $40 \mu \mathrm{m}$ and the thickness of the bacterial cellulose films with the highest extract content was $60 \mu \mathrm{m}$.

The differences in the value thickness of the research results with the literature occurred due to the difficulty of bacteria cellulose pellicle thickness controlling during the harvest resulting from the difficulty in controlling the bacterial growth activity. Furthermore, the amount of water evaporating during the process of drying the bacteria cellulose at room temperature for 4 days was also difficult to control. Consequently, the dry film thickness of the bacterial cellulose became difficult to control.

\section{Conclusion}

- $\quad$ The FTIR analysis showed the shift of the $\mathrm{O}-\mathrm{H}$ peak clusters and $\mathrm{C}=\mathrm{C}$ clusters in the phenolic compounds. This may indicate a weak interaction between the hydroxyl clusters of the bacteria cellulose and the functional clusters of the bioactive compound extract.

- The cancer cell viability test with MTT Assay showed that the sample with $2 \%$ extract concentrations was able to kill the T47D cells in a great number that is equal to $25.47 \%$. This ability is rather low due to the capability to kill the cancer cell. This might be because the type of T47D is more malignant than other cancer cell type.

- The morphology test with SEM, the Bacterial cellulose- 2\% concentration of Garcinia mangostana extract had $12.2 \mu \mathrm{m}$ thickness, thicker than the control sample with $5.63 \mu \mathrm{m}$ thickness. An increase in the film thickness possibly indicate the existence of mangosteen peel extract particles that are trapped in the pores of bacterial cellulose films that have not been dried.

\section{Acknowledgements}

The author would like to thank Cancer Chemoprevention Research Centre Universitas Gadjah Mada for the breast cancer cells T47D and Institute of Tropical Disease Universitas Airlangga for the T47D breast cancer cells handling.

\section{References}

[1] Aka, Juliette A. and Lin, Sheng-Xiang. 2012. Comparison of Functional Proteomic Analyses of Human Breast Cancer Cell Lines T47D and MCF7. Québec : PlosOne.

[2] Akao Y, Nakagawa Y, Iinuma M, and Yoshinori N. 2008. Anti-cancer Effects of Xanthones from Pericarps of Mangosteen. International Journal of Molecular Science. Gifu International Institute of Biotechnology, Japan.

[3] American Cancer Society. Cancer Facts and Figures 2015. Atlanta, Ga : American Cancer Society.

[4] Azizi E, Namazi A, Kaabinejadian S, Foudladdel Sh, Rezaei P, Ramezani M. 2010. Molecular Analysis of MEN1 Expression in MCF7, T47D, and MDA-MB 468 Breast Cancer Cell Lines Treated with Andriamycin Using RT-PCR and Immunocytochemistry. Department of Biochemistry, Tehran University, Iran. 
[5] Chaverri, JP, Rodríguez, NC, Ibarra, MO and Jazmin M. Pérez-Rojas. 2008. Medicinal properties of mangosteen (Garcinia mangostana). Food and Chemical Toxicology 46: 3227-3239.

[6] Dahab RA, Afifi F, Kasabri V, Majdalawi L, and Randa Naffa. 2012. Comparison of the antiproliferative activity of crude ethanol extracts of nine salvia species grown in Jordan against breast cancer cell line models. The University of Jordan, Amman : Pharmacognosy Magazine.

[7] Data Riset Kesehatan Dasar 2013, Badan Litbangkes Kementrian Kesehatan RI dan Data Penduduk Sasaran, Pusdatin Kementrian Kesehatan RI.

[8] Dojindo Molecular Technologies Inc. 2016. Measuring Cell Viability / Cytotoxicity.https://www.dojindo.com/Protocol/Cell_Proliferation_Protocol_Colorimetric.pdf

[9] El-Saied H, Basta AH, Gobran RH. 2004. Research progress in friendly environmental technology for the production of cellulose products (Microbial cellulose and its application). Polym. Plast. Technol. Eng.;43:797-820.

[10] Fernandez P, Wilson C, Hoivik D, and Safe S.H. 1998. Altered phenotypic characteristicsof T47D human breast cancer cells after prolonged growth in estrogen-deficient medium. Cell Biology International : Wiley Online Library.

[11] Gakhar G, Hua DH, and Thu Annelise Nguyen. 2010. Combinational treatment of gap junctional activator and tamoxifen in breast cancer cells. HHS Public Access : Kansas State University, USA.

[12] Long KA, Jackson JK, Yang C, Chehroudi B, Brunette DM, Burt HM. 2009. Controlled release of alendronate from polymeric films. J. Biomater. Sci., Polym. Ed.20:653-672.

[13] Melo L, Bott TR, Fletcher M and B. Capdeville. 2012. Biofilms-Science and Technology. Springer Science and Business Media.

[14] Pusat Data dan Informasi Kementrian Kesehatan Republik Indonesia. 2015. Stop Kanker. Jakarta : Kementrian Kesehatan Republik Indonesia.

[15] Radde BN, Ivanova MM, Mai HX, Salabei JK, Hill BG, and Carolyn M. Klinge. 2015. Bioenergetic Differences between MCF-7 and T47D Breast Cancer Cells and Their Regulation by Oestradiol and Tamoxifen. Louisville, USA : University of Louisville School of Medicine.

[16] Rahayu, Tutiek dan Rohaeti, Eli. 2012. Sifat Mekanik Selulosa Bakteri dari Air Kelapa dengan Penambahan Kitosan. Yogyakarta : FMIPA Universitas Negeri Yogyakarta.

[17] Riss TL, Moravec RA, Niles AL, Benink HA, Worzella TJ, and Lisa Minor. 2015. Assay Guidance Manual. National Center for Biotechnology Information : USA.

[18] Taokaew S, Nunkaew N, Siripong P, and Phisalaphong, M. 2014. Characteristics and anticancer properties of bacterial cellulose films containing ethanolic extract of mangosteen peel. Journal of Biomaterials Science. Chulalongkorn University and National Cancer Institute of Thailand. 